\title{
May the Wind Be at Your Back
}

\section{Matko Marušić ${ }^{1}$}

With this issue, the Faculty of Maritime Studies Split is starting a scientific journal, Transactions on Maritime Science. This I salute for two reasons: firstly because a scientific journal is culturally a very important achievement (Marušić, 2005; Marušić, 2006), and secondly because the editors have kindly asked my advice, considering me a seasoned editor (Marušić, 2010). They also asked me to write (a long) editorial for the first issue. This gives me the opportunity to offer my recommendations for the future of the journal, which I like to do (Marušić, 2010; Marušić, 2011). I wish the Transactions all that its editors certainly dream of - indexing in prestigious databases and then a decent impact factor. With good and dedicated work, this will take about a decade (Marušić and Marušić, 2002), and I will be safe even if that does not happen: advice was given (even published), and my work and responsibilities are over; anything else I do will constitute an added value, but the full responsibility is on the editors.

Starting a new scientific journal, especially in a small scientific community, is a daring, long-lasting and never-ending endeavour - one should think twice before embarking on such a task (Marušić, 2010; Marušić, 2011). Just as authors publish for many different reasons, so do editors start a new journal for different reasons, not only because they want to present the latest scientific discoveries, but also to teach, to inform, to console, to amuse, to stimulate discussion, to make money.

\section{KEY WORDS}

$\sim$ Journals

$\sim$ Publishing

$\sim$ Open access

$\sim$ Indexing

$\sim$ Responsible publishing

\section{WHY A NEW JOURNAL?}

A scientific journal primarily promotes research culture in the community (Marušić and Marušić, 1995). The journal, in a very special way, is a centre of scientific activity; it sets scientific criteria and helps researchers make their work public (Marušić and Marušić, 1999). It also represents the local scientific community to the rest of the world. This is especially important for smaller and economically less privileged countries because via a scientific journal they can join the mainstream science, learn from it, and contribute to its achievements (Marušić et al., 2006; Marušić and Marušić, 2007; Marušić and Marušić, 2009). Good journals in small communities open the doors and windows to the world: doors because publishing in a local journal with international criteria will increase local criteria, knowledge and research integrity, and windows because the rest of the world can see and judge local science (Marušić and Marušić, 1999).

Although it is almost certain that scientists from a small and less developed country will not make any really significant discovery, supporting science in such countries is almost equally if not more important than in the large and developed ones. For small nations, the fastest route to advancement, progress, and closing or narrowing the gap to the developed countries is precisely through the development of science. Scientists are those who can most easily receive knowledge from the more developed countries and pass it on to the younger generations (Marušić, 2005). In other words, scientists are best students and best teachers. And there is no progress without learning.

Since the quality and quantity of scientific work is assessed on the international level - through scientific publications, which include at least two very strong control mechanisms - reviewing of the reports and their permanent visibility after publication - cheating is rendered practically impossible (Marušić, 2008); this means that science by itself is an activity that fosters and maintains integrity and honesty. Since there are no results without real and hard work, science develops working habits, orderliness, punctuality, and other virtues indispensable for personal and national progress (Marušić, 2005). 


\subsection{Audience}

As knowledge is the property of the whole humankind, scientists - wherever they are - should contribute to the generation of new scientific knowledge. The audience of a scientific journal can thus only be the global scientific community (Marušić, 2005). Some local scientific communities will contribute less and some other much more, but even the smallest contribution is addition to the global knowledge (Mohr, 1977). A scientific journal may publish articles of different quality and impact, but the key principle of internationality remains unchanged: a scientific journal must be open to all and aim at all scientists (Marušić, 1992).

\subsection{Language}

Publishing in a national language is necessary and important for the local community, and journals addressing national educational and professional issues should therefore exist and be supported (Nylena et al., 2003; Sambunjak et al., 2009). However, English language has become the language of global science, so a new journal striving to make contributions to the global knowledge usually decides to publish in English. This is a pragmatic question - an effort to achieve recognition and acceptance in international research circles. It is harder to attract authors and readers if the international presentation of the journal is limited, and the same is true for citations, indexing in bibliographic databases, subscription and electronic publishing.

\section{THE NICHE}

The most important thing for a new (particularly small) journal is its profile, the niche it aims to fill in the crowded world of scientific journals (Marušić et al., 2005). Determination of the niche is directly related to the reasons why the journal was started. The journal may have educational, scientific, or professional purpose(s), and this purpose determines its readership. The characteristics of the readership determine the language of the journal, and the purpose of the journal determines the sources of financing (Marušić and Marušić, 2009).

There are many good scientific journals in the world, both in the mainstream science and the so-called "scientific periphery". They cover all areas of research, even the smallest and most specific ones (Marušić and Marušić, 2009), and a new journal cannot often rely on the idea that it will be scientifically either better or more original than other journals. Therefore, if not endowed with some specificity, a new journal will immediately be lost in the endless pool of similar but already established journals. Thus, the first step of considering establishing a new journal is to find its place, its specific niche in the scientific world and then build its profile and all its other features accordingly (Marušić et al., 2005). The small cannot compete with the great in hot topics of the mainstream science, in the medical example (which I know)
- the heart physiology or molecular biology in medicine. Thus, they should seek their chance, even advantages, in the specific areas and ideas, needs, environmental characteristics, and social and political specificities of the country/ies they represent. In other words, local problems, even tragedies such as war (Marušić and Marušić, 2002; Sambunjak and Ivaniš, 2006), can be sources of precious knowledge for all mankind. It is impossible to give more specific advice on the question of journal's niche - except to reiterate that the founders of a new journal first have to define why they want to start it. A sincere answer to this question is the best beginning for a journal (Lacković, 1992). If the answer is "to have our own journal" on a specific topic, the life of the journal will be hard and, more often than not, brief.

\section{LEGAL STATUS}

Journals in small scientific communities usually start as an enthusiastic effort of an individual within an institution. Journal's legal position, rights and responsibilities are often not clear in a complicated and confusing organization of the system. This perhaps gives a certain freedom to the editor but burdens the position of the journal in the long run. I will take a liberty to strongly advise editors to think about the legal status of the journal and roles all of parties (stakeholders) involved in its making and functioning (Marušić et al., 2003; Huth, 2004). These issues should be considered early on, so that journal may grow into a stable institution embedded in the system, regardless of the system's weaknesses (Marušić and Marušić, 2007). The journal's organizational structure should involve all parties relevant for the journal's existence and clearly define their roles. Each party (the owners, publishers, sponsoring institutions, journal boards, editors) should have responsibilities and privileges and none, either by power or by weakness, should endanger the journal's existence and editorial freedom (Marušić et al., 2003).

\section{FINANCING}

There are three important points in running a journal in a small scientific community: first, the journal should have at least some financial independence; second, the publisher should be stimulated to make profit, however small it may be; and third, the financial burden should be distributed among all stakeholders involved. Each involved party must contribute (financially) to the journal because this stimulates responsible behaviour and active involvement (Marušić et al., 2003).

The question of editor's salary is a sensitive one, and should be solved decisively. Editors-in-chief of small learned journals are often active researchers and professionals, who take on the role of journal editor only part time and for a limited period. Editorship is for them more of an honorary position than a real workplace. I strongly recommend such editors not to take money 
for their editorial work if they do not work full time. Volunteer position (they have not become editors or even started the journal because of money but because of genuine enthusiasm) gives the editor more freedom, strengthens his or her editorial independence and reduces possible conflict of interest. Salary for editorial work may be considered only if the growth of the journal requires it, or the editor decides on a full-time position.

\section{PROMOTION}

Small and newly-founded journals have fewer opportunities for promotion than the big and established ones: they have to make their name in the large family of already existing scientific journals. Regardless of the aims of journal promotion, its success is directly related to its quality. This does not mean only the quality of research published, but also the working ethics, quality of editorial work and dedication invested in the journal. It also means the wisdom to find the best niche for the journal, where it could show its quality and value and have greater chance to be recognized by the scientific community (Marušić and Marušić, 2005).

The promotion of a journal can target different populations and goals: it may wish to a) attract good authors, b) get more readers, c) make more money, or d) get included in bibliographic databases. Tactics of reaching these goals and their outcomes often overlap, because one success automatically brings about another one (Marušić and Marušić, 2005).

\subsection{Attracting Authors}

Authors are perhaps the best medium for journal promotion, because a happy author comes back again and also spreads the news of a good new journal. If an author has strong incentive to publish in a specific journal, he or she will not hesitate to pay colour pages, buy reprints, subscribe to the journal, and even recommend advertisements in the journal. Good authors will also be faithful readers and recommend it to other readers and librarians in their institution.

This is a goal whose outcome depends on the editor and the editorial staff. Honest and hard work, prompt responses to authors' manuscripts, and author-helpful policy are the key to success (Marušić and Marušić, 2001; Marušić and Marušić, 2005a, b; Mišak et al., 2005).

Author-helpful policy (Marušić and Marušić, 1999; Marušić and Marušić, 2001, Marušić and Marušić, 2005a, b; Mišak et al., 2005; Marušić et al., 2006) is very important for small journal from small or developing scientific communities, where researchers often have fewer opportunities to do expensive mainstream research and possess poorer writing skills. Journal editor should be a teacher in such a community (Marušić and Marušić, 2004; Marušić and Marušić, 2006; Marušić et al., 2004, Marušić et al., 2006; Mišak et al., 2005) and take active role in educating fellow researchers how to do better research and write better manuscripts (Marušić and Marušić, 2003; Marušić and Marušić, 2004; Marušić et al., 2002, Marušić et al., 2006). Working with the authors for his or her own journal, the editors increase the ability of their authors to publish in other, even better and more influential mainstream journals. Later on, these authors will submit better papers to the journal of their editors-educators, and thus close a positive circle of improving journal quality (Marušić and Marušić, 2001). Such author-helpful policy really works (Marušić et al., 2006) and we recommend it to editors of small journals - it is a lot of work, but it pays of enormously, primarily in the quality and visibility of the journal.

\subsection{Attracting Readers}

Attracting readers is maybe even harder than attracting authors. An author-helpful policy and adequately defined niche of the journal may attract a sufficient number of contributors, but attracting the readers has less strategic ground, and basically cannot be measured. Most editors think, perhaps even subconsciously, that the readers will come along just by themselves - when they have a look at their beautiful new journal. This is wrong: with so many scientific journals around, scientists usually stick to what they know or like or respect, and read little outside their small selection of journals.

However, readers (who are often authors, too) search for information in bibliographic databases or on the Internet and will notice the new journal if the information on its articles is published in these media. Consequently, the two best approaches to increase the readership of the journal and its visibility are: 1) inclusion in bibliographic databases, such as general data bases of the Institute for Scientific Information (Science Citation Index, Current Contents, Web of Science) or specialized data bases, such as Medline for the biomedical field, PsychINFO for psychology, INSPEC for electrical engineering or Agricola for agriculture; and 2) publishing part or full text of the journal on the Internet.

Another approach to make journal more visible is complementary to the two listed above: make the journal available in the libraries of the institutions with potential readership and authorship.

Before deciding on these promotional measures, the editor of a small and new journal will have to make an important decision: whether he or she wants the journal to make money or become visible. Namely, albeit not clear-cut at the first glance, the strategy for making money actually contradicts the strategy aiming to make the journal visible to readers (Kljaković Gašpić et al., 2007). I maintain that the essence of the small journal's strategy is to bring back profit, but that profit not measured in monetary gain.

Most journals in small scientific communities have to rely on financial support from the government or supporting organization. They will probably never become journals based on 
profit, and I recommend them to use the most part their financial subsidy to disseminate information about the journal as widely as possible (Kljaković Gašpić et al., 2007). At least three actions are possible: publishing journal on the web, exchanging journals with other journals, and donating journals to libraries (Marušić et al., 2002; Huić, 2008).

\subsection{Electronic Access to the Journal}

For small journals, just starting and trying to find their place in the large community of scientific journals, electronic visibility is imperative and the best promotional move, especially if the full text of the articles is available for free! Small and new journals do not have many subscribers and do not make profit in the beginning. If they will ever achieve that, it will be only after years of hard work and investment into visibility and quality of the journal.

The cost of making and maintaining journal's web-site is not high for most of the small journals because they can use web-sites and services of their academic or research institutions or associations.

Electronic visibility is especially important for journals still not indexed in bibliographic databases. Web search engines will bring information from the journal to an interested reader - the electronic edition of the journal will thus get more visibility and readers than the paper edition.

Even if the journal is indexed in bibliographic databases which provide abstract of the published articles, they can increase visibility by providing full-text articles on the web, either right after (or even before) the printed version or after some reasonable time (2-6 months). Most established journals practice some form of free access to their articles, without major losses to subscription rates (Kljaković Gašpić et al., 2007).

\subsection{Journal Exchange}

Journal exchange is another way of increasing readership of the printed journal. As most of the small journals are affiliated to research or academic institutions, and the editors are usually professionals in their field, their research activity and contacts can promote the journal. The editor(s) can give the journal to other researchers and ask them to offer exchange to their local journal. This is a noble action: it contains elements of information exchange, collegial cooperation and kindness, simple comradeship, and charity. The gain is twofold. The journal will officially arrive to the (library) of another institution and will be visible to more potential readers. Also, editor's institution will get other journals and thus increase literature pool for their own readers/researchers. The editor's institution could also save some money on institutional journal subscription, which can be an argument for directing some of that money to the new journal.

The editors of small and new journals are strongly advised to become members of editors' associations, such as European Association of Science Editors (EASE), and regularly attend their meetings. In addition to the opportunity to learn a lot about their work as editors and the ways to improve the quality of their work and journal, they can meet other editors, arrange journal exchange and thus further increase the visibility of their journal.

\subsection{Journal Donations}

There are still many financially disadvantaged research communities in the world which are too small and undeveloped and lack both the access to scientific journals in general and existence of a local journal. There are different initiatives, such as HINARI (Aronson, 2004), to provide online access to mainstream journals even in these research environments. Donating your journal, i.e., sending it to libraries of research and academic institution in these countries can also increase the visibility of the journal. Maybe the journal will be even better noticed in an environment without many paper editions of journals. Also, researchers from these environments may be more interested in publishing in smaller journals than in prestigious mainstream journals with high rejection rate.

\section{MAKING PROFIT}

The dream of every editor and publisher is to have many, many subscribers, earn a lot of money so that the work in the journal would depend only on the quality of science. Unfortunately, money is the greatest problem for small journals, creating a vicious circle where lack of money adversely affects the quality and visibility of the journal, which in turn exerts the negative effect to the subscription to the journal; diminishing the subscription diminishes the earnings - which affects quality and visibility (Marušić and Marušić, 1999; Marušić et al., 2005).

As said before, the editor of a small journal should decide before the work on journal promotion whether he or she wants money or visibility. Visibility comes before money (Kljaković Gašpić et al., 2007). In reality, making profit for a small journal in a small country means earning money for sheer survival.

\subsection{Subscribers}

With time and visibility, the journal can focus on subscribers - now it has a good product and the promotion will certainly be more successful.

It is difficult to give advice on best ways to increase subscription. Perhaps the best is to find big publisher and become one in the big family of journals. In this case, all promotional activities are done by the publisher which makes them more successful because the journal is usually offered for subscription with a number of more influential journals, wanted by most libraries (Kljaković Gašpić et al., 2007).

To small journals that chose to stay with a small independent publisher or institution as publisher, I can recommend only to carefully choose the target group of potential subscribers. Little will be achieved by sending out (expensive) advertising leaflets 
to many addresses. It is better to concentrate on specific groups or promote the journal at carefully chosen conferences. Journal authors can be utilized as the promotion medium, asking them to recommend journal subscription to the librarians in their institutions.

With the increase in quality and visibility, research topics published in the journal may attract interest of specific professional associations and some of them may ask the journal to be their official publication with membership subscription. This must be utilized in a precise manner, at least so that the association in question subscribes at least a portion of its members to the journal (Marušić et al., 2003).

\subsection{Advertisements}

Advertisements do bring income, but present a sensitive ethical issue for journal editors because they are thorn between the profit and responsibility towards their readers (Smith, 2003). The most recent version of the Uniform Requirements for Manuscripts Submitted to Biomedical Journals: Writing and Editing for Biomedical Publication (www.icmje.org) state: Journals should have formal, explicit, written policies for advertising in both print and electronic versions; website advertising policy should parallel policy for the print version as much as possible. Editors must have full and final authority for approving advertisements and enforcing advertising policy.

Editor of a small journal will have problems finding advertisements in the beginning, but will probably be approached by advertising companies as the journal becomes visible and respected. This is true especially for journals serving as official publications of a professional association - advertising agencies are interested in reaching as many as possible members of the population working in a given professional field. The journals targeting very small groups or general (non-national) scientific audience will always have problems with advertising.

\subsection{Selling Reprints and Journal Copies}

This is a considerable source of income, even for small journals. In principle, most of the authors gladly buy reprints and journal copies, even pay additional fee for colour pictures. The authors should be informed in time of the rules, prices, and deadlines. Moderate prices will attract more authors.

\subsection{Electronic Access Fee}

Most established journals request a fee for access to their electronic edition. Many also provide free access to their archives. For a small journal, the best promotional strategy, at least in the beginning, is to drop any access fees to their electronic edition. Promotion should come before profit. In that sense, the most profitable action is investing in the development of journal's web edition (Kljaković Gašpić et al., 2007).

\section{Indexing in Bibliographic Databases}

Indexing the journal in bibliographic databases is both the aim and the outcome of its promotion. Indexing in most widely used science information databases means an automatic, objective, and permanent journal promotion, and should be the key strategic goal of journal promotion, existence, and growth. Visibility brings about readers, authors and citations, stability and strength, and finally at least some financial gain and independence (Marušić et al., 2006). This is especially true in the environments where publishing in indexed journals is a prerequisite for academic promotion. Journals indexed in major bibliographic indexes cannot fail (Marušić and Marušić, 2004). Indexing brings about a completely different attitude to journal promotion: after indexing it can concentrate on detail and specificities, because most of the work has been accomplished. Indexing will attract enough authors, which guarantees survival.

Regardless of its importance and desirability, the editor should not hurry with applications for indexing! The rules and conditions of each target database should be studied carefully and fulfilled completely, and more. Rejection is not only painful, but often also carries along a period during which the new application is not acceptable. In any case, hastily reapplication has less chance than the first one. Shortly, when applying for inclusion in a database, the editor must be sure that the journal will be accepted (Marušić and Marušić, 2002).

\section{SUCCESS OR FAILURE}

A journal (and its editor) is successful when it has a steady inflow of manuscripts, regular publishing, visibility in bibliographic databases, editorial independence and integrity, and relative financial independence. This is not easy to achieve in a small journal, especially if it is produced in a small scientific community. General quality standards are the same for all journals, but small journals, even when published in English, are adversely affected by many factors (Marušić and Marušić, 1999). These are the small pool of authors who can produce scientifically strong studies; small and unreliable pool of reviewers; poor, biased and unstable financial resources; and difficulty in achieving perfection in English language. These factors close a vicious circle of inadequacy (Marušić and Marušić, 1999), which can be overcome only by a bold breakthrough. The essence of this breakthrough is hard and highly ethical work (Marušić and Marušić, 2007; Marušić et al., 2007; Marušić, 2011). New, small journals can expect fair treatment and friendly assistance from big, established journals, editors' associations, bibliographic institutions, and international scientific community in general. However, the strength and key to success is in themselves and their work.

To make a long story short, the list of parameters of a successful journal's work is this (Tobin, 2004): 
1. submitted manuscripts;

2. profitability \& distribution;

3. publication lag;

4. serving needs of our members/readers;

5. involvement of readers (letters to the editor);

6. readability;

7. use of advances in technology (internet, pdf, email);

8. editorial processes to ensure integrity of contents;

9. editorial independence;

10. fairness to authors;

11. improved practice.

\section{FINAL ADVICE}

The multitude of advices listed in this text can be narrowed down to two essential ones (Marušić, 2011).

First, the editor should not stop thinking of what is the true niche (purpose) of his/her journal. Science is much wider, much more versatile than it looks at the first glance. So, a smart editor can handsomely perfect the niche of his or her journal by carefully watching for the journal's position in the "science versatility spectrum. "In other words, do not compete with the bigger and better in the mainstream science, find where you are special, interesting, internationally important, where you are better.

Second, the editor should never, ever, get tempted to be influenced in his/her decisions by anything but science. Only perfect honesty and honest objectivity, makes a good journal. Once you start "trading" and making deals, there is no return. There are no deals in editorial work.

I do not wish you the calm seas, Transactions on Maritime Science, because you cannot have it; instead I wish the wind be at your back, to take you to high seas and many exciting adventures in publishing..

\section{REFERENCES}

Aronson, B., (2004), Improving online access to medical information for low-income countries, The New England Journal of Medicine, 350(10), pp. 966-968., http://dx.doi.org/10.1056/NEJMp048009

Huic, M., (2008), Fifteenth anniversary of the Croatian Medical Journal: still moving ahead, Croatian Medical Journal, 49(1), pp. 1-7., http://dx.doi.org/10.3325/cmj.2008.1.1

Huth, E.J., (2004), A model of journal governance, Science Editor, 27(3), pp. 102.

Kljaković-Gašpić, M., Petrak, J., Rudan, I. and Biloglav, Z., (2007), For free or for fee? Dilemma of small scientific journals, Croatian Medical Journal, 48(3), pp. 292-299.

Lackovic, Z., (1992), Who needs Croatian Medical Journal?, Croatian Medical Journal, 33(1), pp. 67-77.

Marušić, A., Katavić, V. and Marušić, M., (2007), Role of editors and journals in detecting and preventing scientific misconduct: strengths, weaknesses, opportunities, and threats, Medicine and Law Journal, 26(3), pp. 545-566.
Marušić, A. and Marušić, M., (1995), Struggle for visibility. A small journal in a small country. INASP newsletter, 5(1995), pp. 8-9.

Marušić, A. and Marušić, M. (1999), Small scientific journals from small countries: breaking from a vitious circle of inadequacy, Croatian Medical Journal, 40(4), pp. 508-514.

Marušić, A. and Marušić,. M., (2002), Croatian Medical Journal: kako smo ušli u Current Contents, Ruđer, 3(9), pp. 6.

Marušić, A. and Marušić, M., (2002), What can medical journal editors do in war?, The Lancet, 360, Suppl: s59-60.,

http://dx.doi.org/10.1016/S0140-6736(02)11825-3

Marušić, A. and Marušić, M., (2003), Teaching students how to read and write science: a mandatory course on scientific research and communication in medicine, Academic Medicine, 78(12), pp. 1235-1239.

Marušić, A. and Marušić, M., (2004), Clinical teaching in a time of war, The Clinical Teacher, 1(1), pp. 19-22.,

http://dx.doi.org/10.1111/j.1743-498X.2004.00012.X

Marušić, A. and Marušić, M., (2005), Promotion of journals, especially small scholarly journals, In: Science Editors' Handbook, European Association of Science Editors, available at: http://www.ease.org.uk/handbook/indeks.shtml/, [accessed 20 September 2011.].

Marušić, A. and Marušić, M., (2005a), Should editors train authors in science communication?, European Science Editing 31(3), pp. 81-83.

Marušić, M., (1992), Editorial: the first issue of the Croatian Medical Journal, Croatian Medical Journal, 33(1), pp. 1-2.

Marušić, M., (2005), Science and patriotis, Macedonian Academy of Sciences and Arts, Contributions, Section of Biological and Medical Sciences, 26(1), pp. 5-11.

Marušić, M., (2006), Važnost znanosti za Hrvatsku i Hrvatske za znanost, In: Ministarstvo znanosti, prosvjete i športa. Zbornik. Prvi kongres hrvatskih znanstvenika iz domovine i inozemstva, Vukovar 15.-19. studenoga 2004., Zagreb: Ministarstvo znanosti, obrazovanja i športa, pp. 366-378.

Marušić, M., (2010), Life of an editor, Zagreb: Croatian Medical Journal and Medicinska naklada.

Marušić, M., (2011), My life as an editor, European Science Editing, 37(1), pp. 19.

Marušić, M., Bošnjak, D., Rulic-Hren, S. and Marušić, A., (2003), Legal regulation of the Croatian Medical Journal: model for small academic journals, Croatian Medical Journal, 46(6), pp. 663-673.

Marušić, M, editor. (2008), Principles of research in medicine, 1st edition, Zagreb: Medicinska naklada.

Marušić, M. and Marušić, A., (2001), Good editorial practice: editors as educators, Croatian Medical Journal, 42(2), pp. 113-120.

Marušić, M. and Marušić, A., (2005b), Organizing the editorial office and educating contributors, In: Science Editors' Handbook. European Association of Science Editors, available at: http://www.ease.org.uk/ handbook/index.shtml/, [accessed 20 September 2011.].

Marušić, M. and Marušić, A., (2007), Threats to the integrity of the Croatian Medical Journal, Croatian Medical Journal, 48(6), pp. 779-785.

Marušić, M. and Marušić, A., (2007), Načela državne politike u vođenju i poticanju izvrsnosti znanstvenih časopisa, In: Vitale B i sur. Četiri stoljeća javnoga zdravstva i biomedicine u Hrvatskoj. Zagreb: Medicinska naklada i Akademija medicinskih znanosti Hrvatske, pp. 354-65. 
Marušić, M. and Marušić, A, (2009), The purpose of scientific journals: small is important, The Journal of Teheran University Heart Center, 4(3), 143-147.

Marušić, M., Markulin, H., Lukić, I.K. and Marušić, A., (2006), Academic advancement of authors receiving tutoring from a medical journal, Teaching and Learning in Medicine, 18(2), pp. 126-129.,

http://dx.doi.org/10.1207/s15328015tlm1802_6

Marušić, M., Marušić, A., King, R., and Tamber, S.P. (2005), Establishing a new journal, In: Science Editors' Handbook. European Association of Science Editors, available at: http://www.ease.org.uk/handbook/index.shtml, [accessed 20 September 2011.].

Marušić, A., Mišak, A., Kljaković-Gašpić, M., and Marušić, M., (2002), Educatione ad excelentiam - ten years of the Croatian Medical Journal, Croatian Medical Journal, 43(1), pp. 1-7.

Marušić, M., Mišak, A., Kljaković-Gašpić, M., Fišter, K., Hren, D. and Marušić, A., (2004), Producing a scientific journal in a small scientific community: an author-helpful policy, International Microbiology, 7(2), pp. 143-147.

Marušić, A., Sambunjak, D. and Marušić, M., (2006), Journal quality and visibility: is there a way out of the scientific periphery?, Macedonian Academy of Sciences and Arts, Contributions, Section of Biological and Medical Sciences, 27(1), pp. 151-161.

Marušić, M., Sambunjak, D. and Marušić, A., (2006), Life of small medical journal how bibliographical indexing and international visibility affected editorial work in Croatian Medical Journal, Croatian Medical Journal, 47(3), pp. 372-375.

Mišak, A., Marušić, M. and Marušić, A., (2005), Manuscript editing as a way of teaching academic writing: experience from a small scientific journal, Journal of Second Language Writing, 14(2), pp. 22-31., http://dx.doi.org/10.1016/j.jslw.2005.05.001
Mohr, H., (1977), Lectures on structure and significance of science, New YorkHeidelberg: Springer Verlag

Nylena, M., Hagve, T-A. and Marušić, A., (2003), Small journals and non-English journals, In: Godlee F, Jefferson T. Peer review in health sciences. London: BMJ Books, pp. $140-150$.

Sambunjak, D. and Ivaniš, A., (2006), Survive, help, learn: experience of a medical journal in war and post-war times, Journal of Public Health Policy, 27(2), pp. 124135.

http://dx.doi.org/10.1057/palgrave.jphp.3200070

Sambunjak, D., Huić, M., Hren, D., Katić, M., Marušić, A. and Marušić, M., (2009), National vs. International Journals: Views of Medical Professionals in Croatia, Learned Publishers, 22(1), pp. 57-70.,

http://dx.doi.org/10.1087/095315108X378785

Smith, R., (2003), Medical journals and pharmaceutical companies: uneasy bedfellows, British Medical Journal, 326(7400), 1202-1205. http://dx.doi.org/10.1136/bmj.326.7400.1202

Tobin, MJ, (2004), Assessing the Performance of a Medical Journal, American Journal of Respiratory and Critical Care Medicine, 169(12), pp. 1268-1272., http://dx.doi.org/10.1164/rccm.2404006 